\title{
Geothermobarometry of Granitic Pegmatites of Nagamalai- Pudukottai area, Madurai Block, South India
}

\author{
Manu Raj R. and Kumar S. N. \\ Department of Geology, University of Kerala, Karyavattom campus \\ Thiruvananthapuram, Kerala 695 581, India \\ Email: manuraj1331@gmail.com
}

\begin{abstract}
The pegmatites in the Neoproterozoic A-type granites of NagamalaiPudukottai area are of two types- gray and pink. These pegmatites contain hornblende. In this work an attempt is made to understand the nature of magma, the process of crystallisation and the Pressure-Temperature (P-T) conditions of formation of the rock with the help of the Electron microprobe (EPMA) study of hornblende from both varieties of pegmatites.

The EPMA of the hornblende from the granitic pegmatites indicate their calcic nature. The structural formula of these calcic amphiboles corresponds to hastingsite. The Altot pressure calibration suggests the formation of the gray and pink pegmatites to be 5 kilobar (average). Based on the amphibole-plagioclase thermometer the magmatic temperature deduced for gray and pink pegmatites is $760^{\circ} \mathrm{C}$ and $745^{\circ} \mathrm{C}$ respectively. These temperature values suggest the later formation of pink pegmatites. The study reveals the formation of the granites and associated pegmatites from a less evolved, hydrous, and less viscous calcic melt in the upper crust.
\end{abstract}

Keywords: Granites, Granitic pegmatites, amphibole, geothermometry, geobarometry

\section{INTRODUCTION}

Mineral assemblages in magmatic rocks and their compositions are related to the source melt and have a crucial connection with the physicochemical conditions during their crystallization (Clarke, 1992). A study of equilibrium mineral assemblages helps to unravel the temperature and pressure of formation of magmatic rocks. Amphiboles invariably represent in abundance the ferromagnesian silicates in granitic rocks. These amphiboles in granitoids are important as they play a major role in the geochemical evolution of parent magma (Martin, 2007).

Amphibole is stable in a wide range of P-T conditions (Blundy and Holland, 1990; Femenias, 2006). Aluminium content in amphibole is affected by the magma composition, temperature and pressure and oxygen fugacity during crystallization. Hence it is used in hornblende barometers, hornblende-plagioclase thermometers and estimation of oxygen fugacity $\left(\mathrm{fO}_{2}\right)$ (Hammarstorm and Zen, 1986; Hollister et al., 1987; Johnson and Rutherford, 
1989; Schmidt, 1992; Ghani, 2000; Stein and Dietl, 2001). Evaluation of P-T conditions from the mineral chemistry of amphiboles is ideal for calc-alkaline intrusions (Femenias, 2006; Sabzian et al., 2015).

In this study, EPMA data of amphiboles in granitic pegmatites of NagamalaiPudukottai area is used for amphibole characterization and to understand the P-T conditions of crystallization of pegmatites.

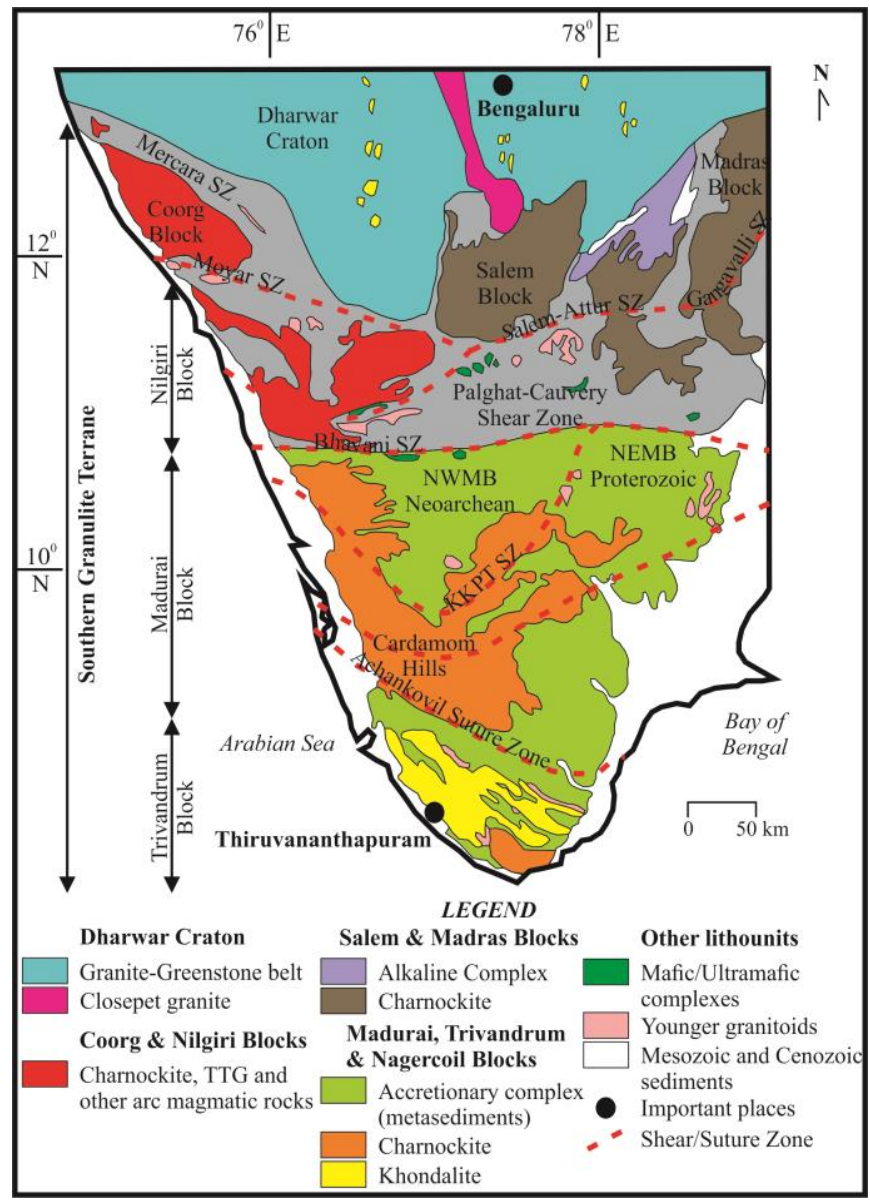

Fig.1: Generalized geological and tectonic framework of the Southern Granulite Terrane of India showing the major crustal blocks and intervening suture zones (after Collins et al., 2014; Santosh et al., 2016). The tectonic sub-divisions of the Madurai Block are modified after Plavsa et al., 2014.

\section{GEOLOGICAL SETTING}

Madurai Block is the largest crustal block in southern India (Fig.1). It is bounded by the Palghat-Cauvery shear system in the north and the Achankovil lineament in the south (Ramakrishnan,1994). The predominant rock types include high-grade metasediments (biotite gneiss, quartzite, marble, khondalitic assemblage), mafic granulites, charnockite massifs and massif-type anorthosite bodies (Ramakrishnan, 1994; Jayananda and Peucaut, 1996). Igneous emplacement ages are Neoproterozoic ( 800 Ma), but the granitic protoliths have incorporated older crustal components up to ca. $3 \mathrm{Ga}$ (Santosh et al., 2003). Detrital zircon ages are as old as $3.2 \mathrm{Ga}$, whereas younger granites were emplaced at $\sim 0.8-0.6 \mathrm{Ga}$ (Ghosh, 1999; Santosh et al., 2003; Ghosh et al., 2004; Collins and Santosh, 2004). P-T-t estimates on sapphirine granulites suggest an ultra-high temperature (UHT) metamorphic 
event, accompanied by ductile deformation and granite intrusion (Choudhary et al., 1992; Mohan and Windley, 1993; Raith et al., 1999; Tsunogae and Santosh, 2007). This may relate to an early component of the pervasive late Neoproterozoic to early Palaeozoic (PanAfrican) overprint as revealed by $0.45-0.6 \mathrm{Ga}$ zircon rims, monazite and uraninite ages (Santosh et al., 2003). The Cambrian-Ordovician ages as well as their distinct alkaline chemistry relate to post-orogenic magmatism in an extensional setting for a suite of younger granites that occurs within the Madurai Block as well as within the late Neoproterozoic shear/suture zones in southern India (Rajesh, 2004; Rajesh and Santosh, 2004).

The study area forms part of the Southern Indian high grade granulite-gneissic terrain. The important lithounits in the area are quartzite, gneisses, charnockite, granites, pegmatites and dolerite (Fig. 2). The different types of gneisses include biotite gneiss, garnetiferous biotite gneiss, garnetiferous biotite sillimanite gneiss and hornblende gneiss.

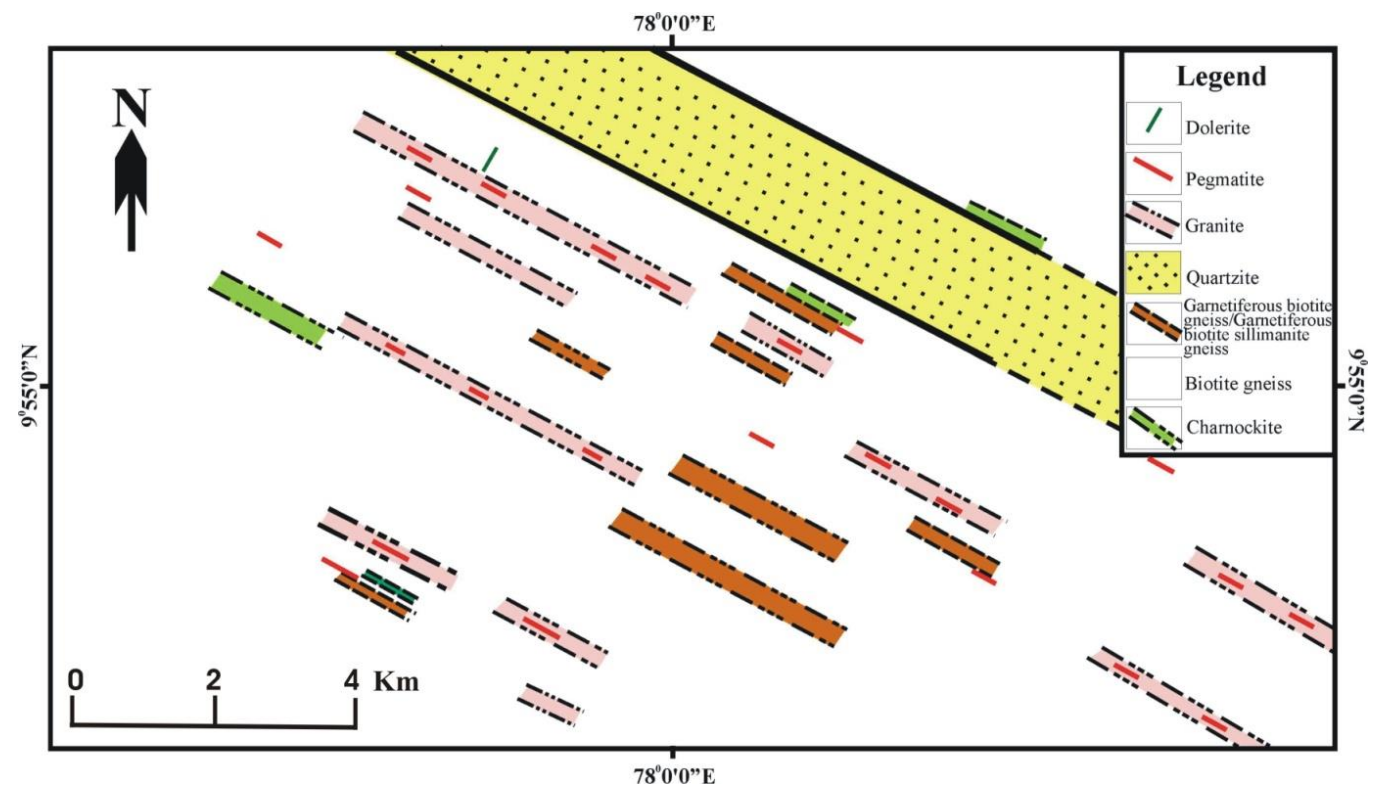

Fig. 2: Lithological map of the Nagamalai-Pudukottai area.

The Nagamalai-Pudukottai granite is emplaced along the Vaigai lineament and is located in the Madurai block of Southern Granulite Terrain. The granites in the study area are of two varieties- gray and pink. Both the granites contain quartz, feldspars (alkali feldspars and plagioclase), biotite and hornblende. The field, textural, mineralogical and geochemical data of these granites point to their A-type origin (Pandey et al., 1994; Manu Raj, 2011; Remya, 2011). The granites are traversed by two types of pegmatites-gray and pink feldspar bearing. The pegmatites are generally of simple type, but are characterised by the presence of polymetallic sulphides (Manu Raj and Kumar, 2015 and 2017).

The pegmatites intruding the granites show sharp contacts. Based on colour and mineralogy, the pegmatites of the area can be broadly divided into two major types viz. gray pegmatites and pink pegmatites. Thin sections of both gray and pink pegmatites reveal that the rock is essentially made up of quartz, perthite, orthoclase, plagioclase, biotite and hornblende as dominant minerals; calcite occur as minor phases (Manu Raj and Kumar, 2015). The average modal mineralogy of pegmatites (16 samples of gray and 14 samples of pink pegmatites) is given in Table-1. 
Geothermobarometry of Granitic Pegmatites of Nagamalai- Pudukottai area, Madurai Block, South India: Manu Raj and Kumar

Table-1: Modal analysis of pegmatites.

\begin{tabular}{|c|c|c|c|c|c|c|c|}
\hline Minerals & Quartz & Perthite & Otrhoclase & Plagioclase & Biotite & Hornblende & Opaque \\
\hline Gray Pegmatite & 20.76 & 51.18 & 3.77 & 11.35 & 5.98 & 2.91 & 3.67 \\
\hline Pink Pegmatite & 24.84 & 60.67 & 3.97 & 3.03 & 3.77 & 1.11 & 1.92 \\
\hline
\end{tabular}

\section{AMPHIBOLES IN GRANITIC PEGMATITES}

The hornblende grains in both gray and pink pegmatites are dark green to greenish black and mostly subhedral; occasionally the gray pegmatites contain large euhedral crystals of hornblende. The grains are mostly found in fibrous aggregates. Each grain shows subvitreous lustre and good prismatic cleavages. The size of hornblende grains in gray pegmatites varies from $1 \mathrm{~cm}$ to $4 \mathrm{~cm}$; in pink pegmatites the range is from $0.5 \mathrm{~cm}$ to $2 \mathrm{~cm}$. In thin sections, the hornblende in gray pegmatite shows strong pleochroism (dark green to light green). Basal sections exhibit two sets of cleavages intersecting at $60^{\circ}$ and $120^{\circ}$. Inclusions of opaque minerals are seen within and surrounding the hornblende grains. Hornblende, perthite, plagioclase, biotite, zircon and magnetite association is prominent in both the varieties of pegmatites (Fig. $3 a$ and b).
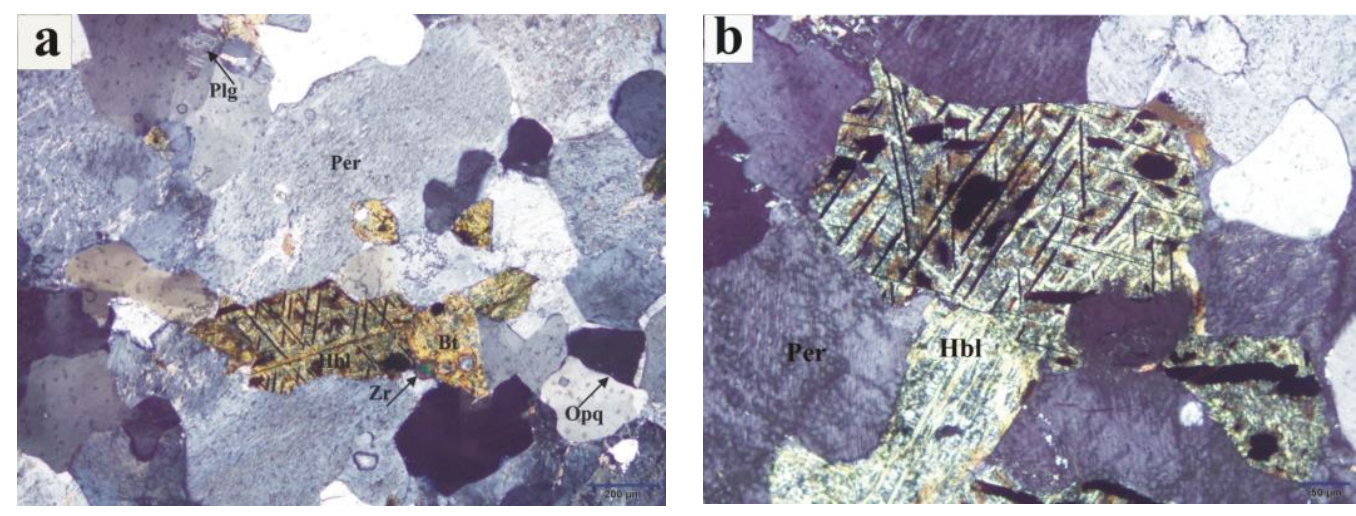

Fig. 3: Photomicrographs of pegmatites. (a) Hornblende, perthite, biotite, plagioclase, opaques and zircon assemblage in gray pegmatite. Note the growth of magnetite grains controlled by cleavages in hornblende (40X). (b) Pink pegmatites showing hornblende and perthite grains. Note the presence of iron oxides in the cleavage traces of hornblende (100X). Per-Perthite, Hbl-Hornblende, Bt-Biotite, PlgPlagoclase, Zr-Zircon, Opq-Opaque.

\section{AMPHIBOLE CHEMISTRY}

Electron microprobe analysis of hornblende and plagioclase from both varieties of granitic pegmatites has been carried out in the Advanced Facility for Microscopy and Microanalysis (AFMM) in the Indian Institute of Science, Bangalore. The analysis was performed with acceleration voltage of $15 \mathrm{keV}$ and beams current of $12 \mathrm{nA}$. The BSE images are given in Fig $4 a$ and $b$.

The amphibole classification after Leake et al. (1997) is followed in this paper. The general amphibole formula is given as $A_{B_{2}} \mathrm{C}_{5} \mathrm{~T}_{8} \mathrm{O}_{22} \mathrm{~W}_{2}$. The general ionic distribution in amphibole in various sites is represented in Table- 2 . Mineral formula calculations are based on 23 oxygens, standardized on 13 cations. Table-3 and 4 represent the structural formulae of amphiboles in gray and pink pegmatites respectively. 
Based on the mineral chemistry (Table-3 and 4), the amphiboles from the gray and pink granitic pegmatites of the study area are classified as calcic-amphiboles. The location of all the amphibole plots in the $(\mathrm{Na}+\mathrm{K})(\mathrm{A})$ vs $\mathrm{Ca}$ diagram supports the same (Fig. 5). The chemical characteristics of the calcic amphiboles in the granitic pegmatites of NagamalaiPudukkottai area make them 'hastingsite'. The inference is based on the following chemical aspects: 1) $\mathrm{Ca} \geq 1.50$; 2) $(\mathrm{Na}+\mathrm{K}) \geq 0.50$; 3) $\mathrm{Ti}<0.50$; 4) $\mathrm{Al}$ vi $<\mathrm{Fe}^{3+}$.
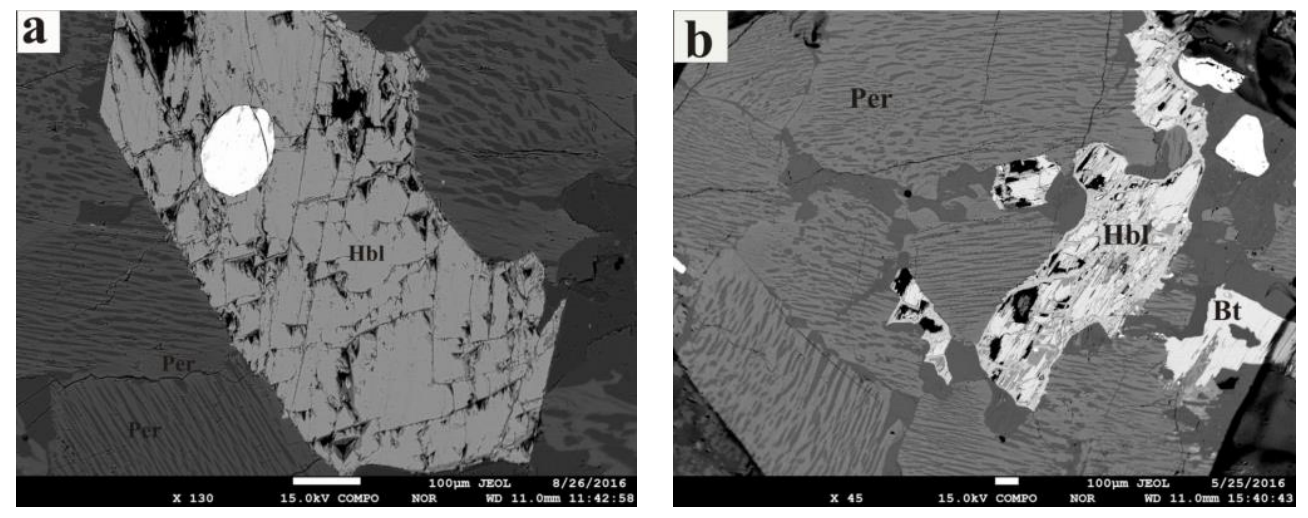

Fig. 4: BSE images of pegmatites (a) Basal section of hornblende and perthites in gray pegmatite. (b) Pink pegmatite showing hornblende, perthite and biotite grains.

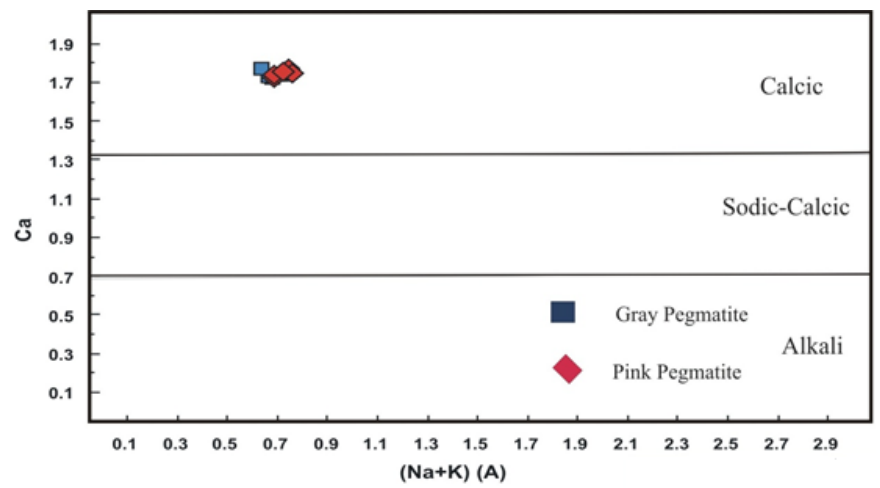

Fig. 5: $(\mathrm{Na}+\mathrm{K})(\mathrm{A})$ vs $\mathrm{Ca}$ diagram for amphiboles in pegmatites.

Table-2: lons in amphibole and its normal occupational sites after Leake et al. (1997).

\begin{tabular}{|c|c|}
\hline lons & Sites \\
\hline$\square$ (empty site), K & $A$ \\
\hline $\mathrm{Na}$ & $A$ or $B$ \\
\hline $\mathrm{Ca}$ & $\mathrm{B}$ \\
\hline L-type ions $\left(\mathrm{Mg}, \mathrm{Fe}^{2+}, \mathrm{Mn}^{2+}, \mathrm{Li}, \mathrm{Zn}, \mathrm{Ni}, \mathrm{Co}\right)$ & $\mathrm{C}$ \\
\hline $\mathrm{Fe} 3+, \mathrm{Mn} 3+, \mathrm{Cr} 3+$ & $\begin{array}{l}\text { C or } B \\
C\end{array}$ \\
\hline High valence ions & $\begin{array}{l}\mathrm{C} \text { or } \mathrm{T} \\
\mathrm{C} \\
\mathrm{T}\end{array}$ \\
\hline Anions $(\mathrm{OH}, \mathrm{F}, \mathrm{Cl}, \mathrm{O})$ & $\mathrm{OH}$ \\
\hline
\end{tabular}

Hastingsite is a calcic amphibole having monoclinic structure with end-member composition " $\mathrm{Na}_{2} \mathrm{Ca}_{2}\left(\mathrm{Fe}^{2+}{ }_{4} \mathrm{Fe}^{3+}\right) \mathrm{Si}_{6} \mathrm{Al} \mathrm{O}_{22}(\mathrm{OH})$ 2. In the current amphibole nomenclature, the name hastingsite has been used for intermediate compositions between pargasite and 
ferrohastingsite (Gaine et al., 1997). In $\mathrm{Mg} /\left(\mathrm{Mg}+\mathrm{Fe}^{2+}\right)$ vs Si diagram, the amphiboles from the granitic pegmatites of the study area falls in the Hastingsite-ferrohastingsite field (Fig. 6).

Ca-amphiboles in both gray and pink granitic pegmatites show a restricted compositional range. The average $X_{M g}[\mathrm{Mg} /(\mathrm{Mg}+\mathrm{Fe})]$ value in gray pegmatites is 0.284 and that of pink pegmatites is 0.277 . The Si value of these amphiboles is low but the amount of Al and alkalis is high.

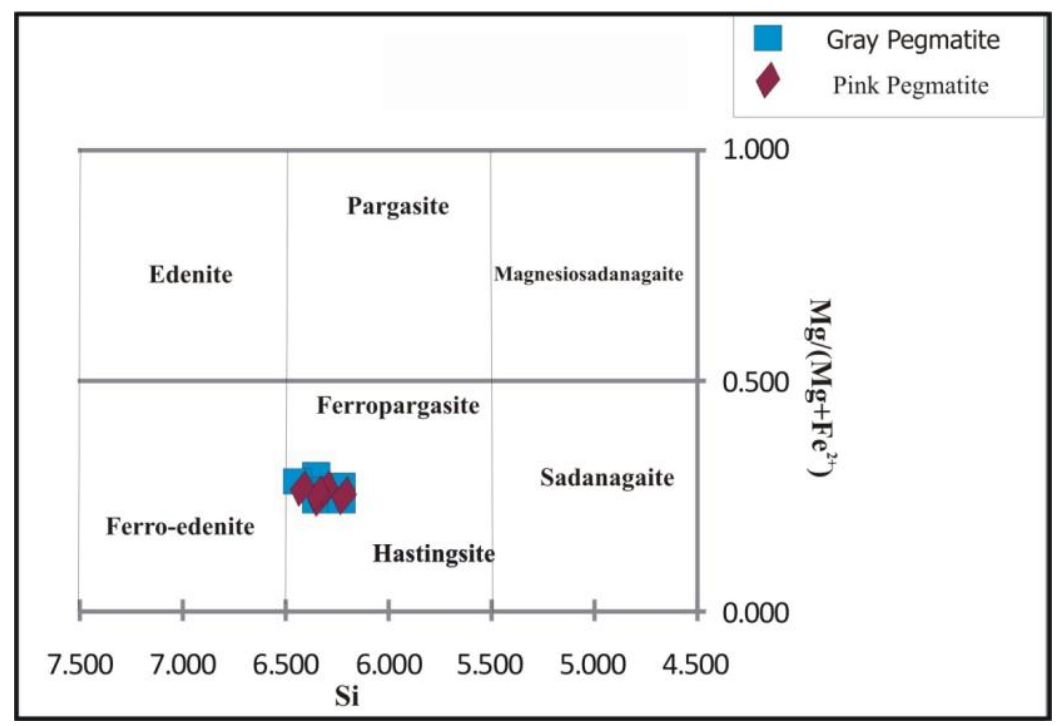

Fig.6: $[\mathrm{Mg} /(\mathrm{Mg}+\mathrm{Fe}]$ vs Si diagram for amphiboles in pegmatites.

\section{GEOBAROMETRY}

The $\mathrm{Al}^{\text {tot }}$ values calculated from the mineral chemistry of amphiboles are used to estimate the pressure of crystallisation of pegmatites. Geobarometry based on Al content in amphiboles is widely used and this in turn helps to determine the depth of emplacement (Ghent et al., 1991; Ague and Brandon, 1992; Anderson and Smith, 1995 and Amiri et al., 2016). Based on Altot content, Hammarstorm and Zen (1986) and Hollister et al. (1987) proposed hornblende geobarometry (empirical geobarometers), for a rock containing quartz + plagioclase + alkali feldspar + hornblende + biotite + titanite + an oxide phase (Magnetite and ilmenite). In addition, some experimental barometers are developed by Johnson and Rutherford (1989) and Schmidt (1992).

The calculated amphibole geobarometer for the granitic pegmatites of Nagamalai-Pudukottai area is listed in Table-5 and 6. The calculated pressure of crystallization for both gray and pink pegmatites is in the range of 4.7 to 5.2 kilobar (average 5 kilobar). The depth of crystallisation is estimated using a conversion factor 1 kilobar $=3.7$ $\mathrm{km}$ (Tulloch and Challis, 2000); for a pressure of $5 \mathrm{kbar}$ the depth is $18.5 \mathrm{~km}$ (for a calculated error factor of \pm 0.5 kilobar, amphiboles crystallized at depth of 16.7 to $20.8 \mathrm{~km}$ ).

\section{AMPHIBOLE-PLAGIOCLASE GEOTHERMOMETER}

As amphibole and plagioclase commonly coexist in calc-alkaline igneous rocks, they are used for calculating the temperature of formation of the rock. Blundy and Holland (1990) proposed a pressure-dependent geothermometer based on tetrahedral aluminium content in calcic amphiboles and albite content in plagioclase. This thermometer is strictly based on the edenite-tremolite reaction. This could be applied to quartz-bearing, intermediate to felsic 
rocks and is calibrated between $500^{\circ} \mathrm{C}$ and $1100^{\circ} \mathrm{C}$. Geobarometric data provided by the amphibole-plagioclase assemblage can be used for thermometric calculations of quartzsaturated rocks (Hammarstorm and Zen, 1992; Rutherford and Johnson, 1992; Poli and and Schimdt,1992). Holland and Blundy (1994) recalibrated the amphibole-plagioclase thermometer based on edenite-tremolite and edenite-richerite reactions which are applicable to quartz-bearing metabasites and quartz-free igneous rocks. According to Anderson (1996), this method can be used successfully for igneous rocks.

For the thermometric calculation of granitic pegmatites of the study area, the chemical data of amphibole and plagioclase are used (Table-3, 4 and 7). On the basis of the calculated pressures, temperatures were calculated after Blundy and Holland (1900) geothermometer (BH90) and Holland and Blundy (1994) geothermometer ( $\left.\mathrm{HB}_{2} 94\right)$. The results are presented in table 8 and 9 . The $\mathrm{BH} 90$ thermometer gives an average temperature of formation of $757^{\circ} \mathrm{C}$ and $747^{\circ} \mathrm{C}$ for gray and pink pegmatites respectively. The average temperature calculated based on $\mathrm{HB}_{2} 94$ for gray and pink pegmatites is $763^{\circ} \mathrm{C}$ and $743^{\circ} \mathrm{C}$ respectively.

The average calculated temperature of formation of gray and pink granitic pegmatites is based on different thermometers is $760^{\circ} \mathrm{C}$ and $745^{\circ} \mathrm{C}$ respectively. The temperature of crystallization of gray pegmatites is higher than that of pink pegmatites. The thermometry data of amphiboles imply their igneous origin (Dada and Ashano, 2013).

\section{DISCUSSION AND CONCLUSIONS}

The amphiboles in granitic pegmatites of Nagamalai-Pudukottai area are of hastingsite type calcic- amphiboles. Calcic amphibole is a common solid-solution mineral in intermediate and felsic rocks; its composition is sensitive to pressure, temperature and bulk composition, making it a potentially useful phase for estimating directly the conditions under which evolved magmas crystallised (Putrika, 2016).

Oxygen fugacity exerts a strong control on the distribution of $\mathrm{Fe}$ and $\mathrm{Mg}$ between coexisting Fe-Mg minerals and melt (Johannes and Holtz, 1996). Amphiboles with high Fe\# $\left[\mathrm{Fe}^{2} /\left(\mathrm{Fe}^{2}+\mathrm{Mg}\right)\right]$ are believed to have been formed under low oxygen fugacity (Anderson and Smith, 1995). The average Fe\# $\left(\left[\mathrm{Fe}^{2+} / \mathrm{Fe}^{2+}+\mathrm{Mg}\right)\right]$ of the pegmatites is 0.72 a.p.f.u, which indicates a low to medium oxygen fugacity (Stein and Dietl, 2001). The low oxygen fugacity nature of the magma is also supported by the high $\mathrm{Al}$ content and $\mathrm{Fe}^{2+} / \mathrm{Fe}^{3+}$ ratio. The high value of $\mathrm{Fe}^{2+} / \mathrm{Fe}^{3+}$ (av. 4.78) in these pegmatites favours the substitution of $\mathrm{Mg}$ by Al. This type of substitutions, known as the pargasite substitution, is dominant in the low to moderate pressure range (Ague, 1989). The low MgO content of the amphiboles in gray (av. 4.81) and pink pegmatites (av.4.67) can be accounted by the pargasite substitution (Vyhnal et al., 1991 and Ghani, 2000). The average $X_{\mathrm{Mg}}$ value in gray pegmatites is 0.284 and that of pink pegmatites is 0.277 .

Aluminium in hornblende barometry indicates that the emplacement pressures for these pegmatites are between 4.8 and 5.2 kilobar (average 5kilobar). $\mathrm{HB}_{2} 94$ thermometer is extensively applied for temperature calculation of igneous plutons. The average temperature of emplacement calculated using the different thermometer is $760^{\circ} \mathrm{C}$ for gray pegmatites and $745^{\circ} \mathrm{C}$ for pink pegmatites. From the geothermobarometric studies, it is seen that the pressure of crystallisation of amphiboles in both pegmatites are very similar, but the temperature of crystallization of gray pegmatites is higher than that of the pink pegmatites. The calcic amphiboles in the granitic pegmatites points to their formation from a calcic magma in the upper crust (Martin, 2007; Papoutsa and Pe-Piper 2014). Calcic magmas are water rich, less evolved and having lower values of viscosity (Papoutsa and Pe-Piper 2014). 
Acknowledgements: The first author is thankful to the Kerala State Council for Science Technology and Environment for providing financial support for carrying out the research work. The present study is part of the Ph.D. work of the first author. The authors are grateful to Dr. Sajeev K., Asst. Professor, IISc., Bangalore, for his help in the EPMA study and fruitful discussion. The authors are also thankful to Dr. K.S. Sajin Kumar, Asst. Professor, Dept. of Geology, University of Kerala, Karyavattom, for help in the preparation of maps and diagrams.

\section{REFERENCES}

Ague, J. J. (1989) The distribution of $\mathrm{Fe}$ and $\mathrm{Mg}$ between biotite and amphibole in granitic rocks: Effects of temperature, pressure and amphibole composition. Geochemical jour., v. 23, pp. 279-293.

Ague, J. J. and Brandon, M. T. (1992) Tilt and northward offset of Cordilleran batholiths resolved using igneous barometry. Nature, v. 360, p. 146-149.

Amiri, M., Khalaji, A. A., Tahmasbi, Z., Sahamieh, R. Z. and Zamanian, H. (2016) Geothermobarometry of amphiboles in intermediate to basic rocks from the Almogholagh pluton in western Iran. Jour. mineralogical and Petrological Sciences, v. 111, pp. 337-350.

Anderson, J. L. (1996) Status of thermobarometry in granitic batholiths. Earth Sciences, v. 87, pp. 125-138.

Anderson, J. L. and Smith, D. R. (1995) The effects of temperature and oxygen fugacity on the Al-inhornblende barometer. Amer. Miner., v. 80, pp. 549-559.

Blundy, J. D. and Holland, T. J. B. (1990) Calcic amphibole equilibria and a new amphibole plagioclase geothermometer. Contrib. Mineral. Petrol., v. 104, pp. 208-224.

Choudhary, A.K., Harris, N.B.W., Van Calsteren, P.and Hawkesworth, C.J. (1992) Pan-African charnockite formation in Kerala, south India. Geol. Mag. v.129, pp. 257-264.

Clarke, D. B. (1992) Granitoid Rocks. Chapman and Hall, London, First Ed. 283p.

Collins, A.S. and Santosh, M. (2004) New protolith provenance, crystallisation and metamorphic U-Pb zircon SHRIMP ages from southern India. In: T.R.K. Chetty, Y.J. Bhaskar Rao (eds.). International Field Workshop on the Southern Granulite Terrane. National Geophysical Research Institute, Hyderabad, India, pp. $73-76$.

Collins, A. S., Clark, C. and Plavsa, D. (2014) Peninsula India in Gondwana: the tectonothermal evolution of the Southern Granulite Terrane and its Gondwanan counterparts. Gondwana Research, v. 25, pp. 190-203.

Dada, O.A. and Ashano, E.C. (2013) Composition of Amphiboles from Toro Dioritic Complex, Northcentral Nigeria: A potential petrogenetic and geothermobarometric indicator. Jour. Geosciences and Geomatics, v. 1, pp. 41-46

Femenias, O. C., Mercier, J. C., Nkono, C., Diot H., Berza, T., Tatu, M. and Demaiffe, D. (2006) Calcic amphibole growth and composition in calc-alkaline magmas: Evidence from the Motru Dike Swarm (Southern Carpathians, Romania). Amer. Minerl., v. 91, pp. 73-81.

Gaine, R.V., Skinner, H.C.W., Ford, E.E., Mason, B. and Rosenzweig, A. (1997) Dana's New Mineralogy, Eighth edition, pp. 1335-1380.

Ghani, A. A. (2000) Hornblende chemistry and its application to geobarometry of the Noring pluton, Stong complex, Kelantan. Geological Soc. Malaysia Annual Geological Conference, pp. 8185.

Ghent, E. D., Nicholls, J., Siminy, P. S., Sevigny, H. H. and Stout, M. Z. (1991) Hornblende geobarometry of the Nelson batholiths, Southeastern British Coloumbia: Tectonic Implications. Canadian Jour. Earth Sci., v. 28, pp. 1982-1991.

Ghosh, J.G. (1999) U-Pb geochronology and structural geology across major shear zones of the Southern Granulite Terrain of India and organic carbon isotope stratigraphy of the Gondwana coal basins of India: their implications for Gondwana studies. Ph. D. Thesis, University of Cape Town, South Africa.

Ghosh, J.G., DeWrr, M.J. and Zartman, R. E. (2004) Age and tectonic evolution of Neoproterozoic ductile shear zones in the Southern Granulite Terrain of India, with implications for Gondwana studies. Tectonics, v. 23, pp.1-38.

Hammarstrom, J. M. and Zen, E. (1986) Aluminium in hornblende: An empirical igneous geobarometer. Amer. Miner., v. 71, pp. 1297-1313. 
Hammarstrom, J. and Zen, E. (1992) Discussion of Blundy and Holland's (1990) "Calcic Caamphibole equilibria and a new amphibole-plagioclase geothermometer". Contrib. Mineral. Petrol., v. 111, pp. 264-266.

Holland, T. and Blundy, J. (1994) Non-ideal interactions in calcic amphiboles and their bearing on amphibole plagioclase thermometry. Contrib. Mineral. Petrol., v. 116, pp-433-447.

Hollister, L. S., Grissom, G. C., Peters, E. K., Stowell, H. H. and Sisson, V. B. (1987) Confirmation of the empirical correlation of $\mathrm{Al}$ in hornblende with pressure of solidification of calc-alkaline plutons. Amer. Minerl., v. 72, pp. 231-239.

Jayananda, M. and Peucaut. J.J. (1996) Geochronological framework of southern India. Gondwana Research Group Memoir-3, The Archaean and Proterozoic Terrains of Southern India within East Gondwana, pp. 53-75.

Johannes, W. and Holtz, F. (1996) Experimental petrology of Granitic rocks. Minerals and Rock Series, v. 22, $335 \mathrm{p}$.

Johnson, M. C. and Rutherford, M. J. (1989) Experimental calibration of the aluminum-in-hornblende geobarometer with application to Long Valley caldera (California) volcanic rocks. Geology, v. 17, pp. 837-841.

Leake, B., Woolley, A., Arps, C., Birch, W., Gilbert, M., Grice, J., Hawthorne, F., Kato, A., Kisch, H., Krivovichev, V., Linthout, K., Laird, J., Mandarino, J., Maresch, W., Nickel, E., Rock, N., Schumacher, J., Smith, D., Stephenson, N., Un-garetti, L., Whittaker, E., and Youzhi, G. (1997) Nomenclature of amphiboles: Report of the Subcommittee on Amphiboles of the International Mineralogical Association, Commission on New Minerals and Mineral Names. Amer. Mineral., v. 82, pp. 1019- 1037.

Manu Raj, R. (2011). Petrological study of granulites and geochemistry of granites of Sakkanurani area, Madurai district, Tamil Nadu. Unpublished M.Sc. Thesis, University of Kerala, Kariavattom.

Manu Raj, R. and Kumar, S. N. (2015) Characterisation of selected sulphides associated with the granitic pegmatites of Nagamalai-Pudukottai area, Madurai District, Tamil Nadu, India. Jour. Applied Geochemistry, v.17 (4), pp-444-450.

Manu Raj, R. and Kumar, S. N. (2017) Chemical characteristics of biotites in post-kinematic granites and associated pegmatites of Nagamalai-Pudukottai Area, Madurai District, Tamil Nadu, South India. Jour. Applied Geochemistry, v. 19 (2), pp.171-182.

Martin, R.F. (2007) Amphiboles in the igneous environment. Rev. Mineral. Geochem., v.67, pp.323354.

Mohan, A. and Windley, B.F. (1993) Crustal trajectory of sapphirine bearing granulites from Ganguvarpatti, south India: evidence for an isothermal decompression path. Jour. Metamorphic Geology, v. 11, pp. 867-878.

Pandey, U.K., Chabria, T., Krishna, V. and Krishnamurthy P. (1994) Rb-Sr geochronology of Late Proterozoic A-type granites in parts of Madurai district, Tamil Nadu: implications on uranium and rare metal exploration. Jour. Atm. Min. Sci., v.2, pp.29-43.

Papoutsa, A. and Pe-Piper, G. (2014) Geochemical variation of amphiboles in A-type granites as an indicator of complex magmatic systems: Wentworth pluton, Nova Scotia, Canada. Chemical Mineralogy, v.384, pp.120-134.

Plavsa, D., Collins, A.S., Payne, J.L., Foden, J., Clark, C. and Santosh, M. (2014) Detrital zircons in basement metasedimentary protoliths unveil the origins of southern India. Geol. Soc. America Bulletin, v. 126, pp. 791-812.

Poli, S., and Schmidt, M. (1992) A comment on "Calcic amphibole equilibria and a new amphiboleplagioclase geothermometer" by J.D. Blundy and T.J.B. Holland (Contrib. Mineral. Petrol., 1990, 104, 208-224). Contributions to Mineralogy and Petrology, v. 111, pp. 273-282.

Putirka, K. (2016) Amphibole thermometers and barometers for igneous systems and some implications for eruption mechanisms of felsic magmas at arc volcanoes. American Mineralogist, v. 101(4), pp. 841-858.

Raith, M. M., Srikantappa, C., Buhl, D. and Köhler, H. (1999) The Nilgiri enderbites, south India: nature and age constraints on protolith formation, high-grade metamorphism and cooling history. Precambrian Research, v. 98, pp. 129-150.

Rajesh, H.M. (2004) The igneous charnockite-high-K alkali calcic I-type granite-incipient charnockite association in the Trivandrum block, southern India. Contri. Mineral. Petrol., v. 147, pp. 346362. 
Rajesh, H.M. and Santosh, M. (2004) Charnockitic magmatism in southern India. Jour. Earth System Science, v.113, pp. 565-585.

Ramakrishnan, M. (1994) Stratigraphic evolution of Dharwar craton. In: B.M. Ravindra and N. Ranganathan (eds.), GeoKarnataka, Karnataka Assistant Geologists' Association, Dept. of Mines and Geology, Bangalore, pp.6-35.

Remya, J. (2011) Petrological study of granulites and geochemistry of granites of Karadipatti area, Madurai district, Tamil Nadu. Unpublished M.Sc. Thesis, University of Kerala, Kariavattom.

Rutherford, M. and Johnson, M. (1992) Comment on Blundy and Holland's (1990) "Calcic Caamphibole equilibria and a new amphibole-plagioclase geothermometer". Contrib. Mineral. Petrol., v. 111, pp. 266-268.

Sabzian, A., Masoudi, F., Harooni, H.A., Emami, M.H. and Nezafaty, N. (2015) Application of feldspar and hornblende composition to investigate the nature and thermobarometry aftabrou pluton northwest uromieh-dokhtar magmatic belt. Iran. Jour. Biodiversity and Environmental Sciences, v. 6, pp. 609-620.

Santosh, M., Yokoyama, S., Biju-Sekhar, S. and Rogers, J.J.W. (2003) Multiple tectonothermal events in the granulite blocks of Southern India revealed from EPMA dating: implications on the history of supercontinents. Gondwana Research, v.6, pp. 29-63.

Santosh, M., Yang, Q.Y., Shaji, E., Ram Mohan, M., Tsunogae, T. and Satyanarayanan, M. (2016) Oldest rocks from Peninsular India: evidence for Hadean to Neoarchean crustal evolution. Gondwana Research, v. 29, pp. 105-135.

Schmidt, M. W. (1992) Amphibole composition in tonalite as a function of pressure: An experimental calibration of the Al-in-hornblende barometer. Contrib. Mineral. Petrol., v. 110, pp. 304-310.

Stein, E. and Dietl, C. (2001) Hornblende thermometry of granitoids from Central Odenwald (Germany) and their implications for the geotectonic development of the Odenwald. Mineral. Petril., v. 72, pp. 185-207.

Tulloch, A. J. and Challis, G. A. (2000) Emplacement depths of Paleozoic-Mesozoic plutons from western New Zealand estimated by Hornblende-Al Geobarometry. New Zealand Journal of Geology and Geophysics, v. 43, pp. 555-567.

Tsunagae, T. and Santosh, M. (2007) Ulltra-high-temperature metamorphism in Southern Indian Granulite Terrain. IAGR Memoir, No. 10, pp. 55-75.

Vyhnal, C.R., Mcsween, H.Y. and Speer, J. A. (1991) Hornblende chemistry in southern Applachian granitoids: implication for aluminium hornblende thermo-barometry and magmatic episode stability. Amer. Miner., v. 79, pp. 176-188. 
Table-3: Analytical results of amphibole in gray pegmatites.

\begin{tabular}{|c|c|c|c|c|c|c|}
\hline Sample & 1 & 2 & 3 & 4 & 5 & 6 \\
\hline $\mathrm{SiO}_{2}$ & 40.136 & 40.079 & 40.18 & 40.543 & 40.607 & 40.879 \\
\hline $\mathrm{TiO}_{2}$ & 1.548 & 1.565 & 1.542 & 1.489 & 1.755 & 1.716 \\
\hline $\mathrm{Al}_{2} \mathrm{O}_{3}$ & 9.387 & 9.805 & 9.609 & 9.632 & 9.587 & 9.576 \\
\hline $\mathrm{FeO}$ & 26.771 & 26.479 & 26.257 & 26.249 & 25.709 & 26.456 \\
\hline $\mathrm{MnO}$ & 0.136 & 0.151 & 0.118 & 0.093 & 0.103 & 0.109 \\
\hline $\mathrm{MgO}$ & 4.826 & 4.754 & 4.816 & 4.854 & 4.853 & 4.732 \\
\hline $\mathrm{CaO}$ & 10.224 & 10.266 & 10.124 & 10.241 & 10.187 & 10.476 \\
\hline $\mathrm{Na}_{2} \mathrm{O}$ & 2.048 & 2.109 & 1.982 & 2.028 & 1.916 & 1.777 \\
\hline $\mathrm{K}_{2} \mathrm{O}$ & 1.763 & 1.729 & 1.725 & 1.769 & 1.72 & 1.677 \\
\hline \multicolumn{7}{|l|}{ Structural formulae } \\
\hline Si & 6.358 & 6.341 & 6.378 & 6.406 & 6.434 & 6.424 \\
\hline $\mathrm{Al}$ iv & 1.642 & 1.659 & 1.622 & 1.594 & 1.566 & 1.576 \\
\hline Al vi & 0.111 & 0.169 & 0.175 & 0.199 & 0.224 & 0.197 \\
\hline $\mathrm{Ti}$ & 0.184 & 0.186 & 0.184 & 0.177 & 0.209 & 0.203 \\
\hline $\mathrm{Cr}$ & 0.000 & 0.000 & 0.000 & 0.000 & 0.000 & 0.000 \\
\hline $\mathrm{Fe}^{3+}$ & 0.706 & 0.642 & 0.676 & 0.597 & 0.529 & 0.568 \\
\hline $\mathrm{Fe}^{2+}$ & 2.841 & 2.862 & 2.809 & 2.872 & 2.878 & 2.909 \\
\hline $\mathrm{Mn}$ & 0.018 & 0.020 & 0.016 & 0.012 & 0.014 & 0.015 \\
\hline $\mathrm{Mg}$ & 1.140 & 1.121 & 1.140 & 1.143 & 1.146 & 1.109 \\
\hline $\mathrm{Ca}$ & 1.735 & 1.740 & 1.722 & 1.734 & 1.729 & 1.764 \\
\hline $\mathrm{Na}$ & 0.629 & 0.647 & 0.610 & 0.621 & 0.589 & 0.541 \\
\hline $\mathrm{K}$ & 0.356 & 0.349 & 0.349 & 0.357 & 0.348 & 0.336 \\
\hline $\mathrm{OH}^{*}$ & 2.000 & 2.000 & 2.000 & 2.000 & 2.000 & 2.000 \\
\hline Total & 17.721 & 17.736 & 17.681 & 17.711 & 17.666 & 17.641 \\
\hline Calculation scheme & $\Sigma 13$ & $\Sigma 13$ & $\sum 13$ & $\Sigma 13$ & $\sum 13$ & $\sum 13$ \\
\hline Amphibole group & $\mathrm{Ca}$ & $\mathrm{Ca}$ & $\mathrm{Ca}$ & $\mathrm{Ca}$ & $\mathrm{Ca}$ & $\mathrm{Ca}$ \\
\hline$(\mathrm{Ca}+\mathrm{Na})(\mathrm{B})$ & 2.000 & 2.000 & 2.000 & 2.000 & 2.000 & 2.000 \\
\hline $\mathrm{Na}(\mathrm{B})$ & 0.265 & 0.260 & 0.278 & 0.266 & 0.271 & 0.236 \\
\hline$(\mathrm{Na}+\mathrm{K})(\mathrm{A})$ & 0.721 & 0.736 & 0.681 & 0.711 & 0.666 & 0.641 \\
\hline $\mathrm{Mg} /\left(\mathrm{Mg}+\mathrm{Fe}^{2}\right)\left(\mathrm{X}_{\mathrm{Mg}}\right)$ & 0.286 & 0.282 & 0.289 & 0.285 & 0.285 & 0.276 \\
\hline $\mathrm{Fe \#}\left(\mathrm{Fe}^{2} /\left(\mathrm{Fe}^{2}+\mathrm{Mg}\right)\right.$ & 0.714 & 0.718 & 0.734 & 0.715 & 0.715 & 0.724 \\
\hline $\mathrm{Fe}^{2+} / \mathrm{Fe}^{3+}$ & 4.024 & 4.460 & 4.152 & 4.814 & 5.544 & 5.122 \\
\hline
\end{tabular}


Table- 4: Analytical results of amphiboles in pink pegmatites.

\begin{tabular}{|c|c|c|c|c|c|c|}
\hline Sample & 1 & 2 & 3 & 4 & 5 & 6 \\
\hline $\mathrm{SiO}_{2}$ & 40.033 & 39.386 & 39.659 & 40.433 & 39.988 & 40.251 \\
\hline $\mathrm{TiO}_{2}$ & 1.415 & 1.466 & 1.305 & 1.519 & 1.525 & 1.553 \\
\hline $\mathrm{Al}_{2} \mathrm{O}_{3}$ & 9.575 & 9.293 & 9.29 & 9.54 & 9.405 & 9.335 \\
\hline $\mathrm{FeO}$ & 25.988 & 26.338 & 26.811 & 26.38 & 25.73 & 26.535 \\
\hline $\mathrm{MnO}$ & 0.101 & 0.126 & 0.135 & 0.137 & 0.117 & 0.14 \\
\hline $\mathrm{MgO}$ & 4.812 & 4.892 & 4.473 & 4.606 & 4.623 & 4.662 \\
\hline $\mathrm{CaO}$ & 10.056 & 10.1 & 10.263 & 10.213 & 10.097 & 10.247 \\
\hline $\mathrm{Na}_{2} \mathrm{O}$ & 1.986 & 2.136 & 2.054 & 1.958 & 2.15 & 2.037 \\
\hline $\mathrm{K}_{2} \mathrm{O}$ & 1.738 & 1.728 & 1.647 & 1.732 & 1.721 & 1.72 \\
\hline \multicolumn{7}{|l|}{ Structural formulae } \\
\hline $\mathrm{Si}$ & 6.395 & 6.332 & 6.381 & 6.421 & 6.439 & 6.406 \\
\hline $\mathrm{Al}$ iv & 1.605 & 1.668 & 1.619 & 1.579 & 1.561 & 1.594 \\
\hline Al vi & 0.198 & 0.092 & 0.143 & 0.206 & 0.224 & 0.157 \\
\hline $\mathrm{Ti}$ & 0.170 & 0.177 & 0.158 & 0.181 & 0.185 & 0.186 \\
\hline $\mathrm{Cr}$ & 0.000 & 0.000 & 0.000 & 0.000 & 0.000 & 0.000 \\
\hline $\mathrm{Fe}^{3+}$ & 0.654 & 0.722 & 0.642 & 0.581 & 0.458 & 0.592 \\
\hline $\mathrm{Fe}^{2+}$ & 2.818 & 2.819 & 2.965 & 2.923 & 3.007 & 2.940 \\
\hline $\mathrm{Mn}$ & 0.014 & 0.017 & 0.018 & 0.018 & 0.016 & 0.019 \\
\hline $\mathrm{Mg}$ & 1.146 & 1.172 & 1.073 & 1.090 & 1.110 & 1.106 \\
\hline $\mathrm{Ca}$ & 1.721 & 1.740 & 1.769 & 1.738 & 1.742 & 1.747 \\
\hline $\mathrm{Na}$ & 0.615 & 0.666 & 0.641 & 0.603 & 0.671 & 0.629 \\
\hline K & 0.354 & 0.354 & 0.338 & 0.351 & 0.354 & 0.349 \\
\hline $\mathrm{OH}^{*}$ & 2.000 & 2.000 & 2.000 & 2.000 & 2.000 & 2.000 \\
\hline Total & 17.691 & 17.760 & 17.748 & 17.691 & 17.767 & 17.725 \\
\hline $\begin{array}{l}\text { Calculation } \\
\text { scheme }\end{array}$ & $\sum 13$ & $\sum 13$ & $\sum 13$ & $\sum 13$ & $\sum 13$ & $\sum 13$ \\
\hline Amphibole group & $\mathrm{Ca}$ & $\mathrm{Ca}$ & $\mathrm{Ca}$ & $\mathrm{Ca}$ & $\mathrm{Ca}$ & $\mathrm{Ca}$ \\
\hline$(\mathrm{Ca}+\mathrm{Na})(\mathrm{B})$ & 2.000 & 2.000 & 2.000 & 2.000 & 2.000 & 2.000 \\
\hline $\mathrm{Na}(\mathrm{B})$ & 0.279 & 0.260 & 0.231 & 0.262 & 0.258 & 0.253 \\
\hline$(\mathrm{Na}+\mathrm{K})(\mathrm{A})$ & 0.691 & 0.760 & 0.748 & 0.691 & 0.767 & 0.725 \\
\hline $\mathrm{Mg} /\left(\mathrm{Mg}+\mathrm{Fe}^{2}\right)\left(\mathrm{X}_{\mathrm{Mg}}\right)$ & 0.289 & 0.294 & 0.266 & 0.272 & 0.270 & 0.273 \\
\hline Fe\# & 0.710 & 0.706 & 0.734 & 0.728 & 0.730 & 0.727 \\
\hline $\mathrm{Fe}^{2+/} \mathrm{Fe}^{3+}$ & 4.306 & 3.903 & 40616 & 5.032 & 6.571 & 4.964 \\
\hline
\end{tabular}


Table-5: Calculated geobarometry for gray pegmatites.

\begin{tabular}{|l|c|c|c|c|c|c|c|c|}
\hline P (kbars) & $\mathbf{1}$ & $\mathbf{2}$ & $\mathbf{3}$ & $\mathbf{4}$ & $\mathbf{5}$ & $\mathbf{6}$ & Average & Average \\
\hline Hammarstrom and Zen, 1986 & 4.9 & 5.3 & 5.1 & 5.1 & 5.1 & 5.0 & 5.1 & \multirow{2}{*}{5.2} \\
\cline { 1 - 7 } Hollister et al., 1987 & 5.1 & 5.6 & 5.4 & 5.4 & 5.3 & 5.2 & 5.3 & \multirow{2}{*}{4.8} \\
\hline Johnson and Rutherford, 1989 & 4.0 & 4.3 & 4.1 & 4.1 & 4.1 & 4.0 & 4.1 & \\
\hline Schmidt, 1992 & 5.3 & 5.7 & 5.5 & 5.5 & 5.5 & 5.4 & 5.5 & \\
\hline
\end{tabular}

Table-6: Calculated geobarometry for pink pegmatites.

\begin{tabular}{|l|c|c|c|c|c|c|c|c|}
\hline P (kbars) & $\mathbf{1}$ & $\mathbf{2}$ & $\mathbf{3}$ & $\mathbf{4}$ & $\mathbf{5}$ & $\mathbf{6}$ & Average & Average \\
\hline Hammarstrom and Zen, 1986 & 5.1 & 4.9 & 4.9 & 5.1 & 5.1 & 4.9 & 5.0 & \multirow{2}{*}{5.1} \\
\hline Hollister et al., 1987 & 5.4 & 5.2 & 5.2 & 5.3 & 5.3 & 5.1 & 5.2 & \multirow{2}{*}{4.7} \\
\hline Johnson and Rutherford, 1989 & 4.2 & 4.0 & 4.0 & 4.1 & 4.1 & 3.9 & 4.0 & \multirow{2}{*}{ Schmidt, 1992 } \\
\hline
\end{tabular}

Table-7: Analytical result of plagioclases from pegmatites.

\begin{tabular}{|c|c|c|c|c|}
\hline & \multicolumn{2}{|c|}{ Gray pegmatite } & \multicolumn{2}{c|}{ Pink pegmatite } \\
\hline & 1 & 2 & 3 & 4 \\
\hline $\mathrm{SiO}_{2}$ & 63.666 & 63.237 & 64.258 & 63.558 \\
\hline $\mathrm{TiO}_{2}$ & 0 & 0 & 0 & 0.007 \\
\hline $\mathrm{Al}_{2} \mathrm{O}_{3}$ & 23.25 & 23.675 & 22.691 & 24.281 \\
\hline $\mathrm{MnO}$ & 0 & 0.018 & 0 & 0.013 \\
\hline $\mathrm{MgO}$ & 0 & 0.014 & 0 & 0 \\
\hline $\mathrm{FeO}$ & 0.086 & 0.108 & 0.049 & 0.092 \\
\hline $\mathrm{CaO}$ & 4.359 & 4.802 & 3.844 & 3.21 \\
\hline $\mathrm{Na}_{2} \mathrm{O}$ & 9.041 & 8.744 & 9.197 & 8.916 \\
\hline $\mathrm{K} 2 \mathrm{O}$ & 0.211 & 0.198 & 0.321 & 0.194 \\
\hline $\mathrm{Total}$ & 100.613 & 100.796 & 100.381 & 100.271 \\
\hline $\mathrm{Si}$ & 11.190 & 11.109 & 11.304 & 11.218 \\
\hline $\mathrm{Ti}$ & 0.000 & 0.000 & 0.000 & 0.001 \\
\hline $\mathrm{Al}$ & 4.816 & 4.901 & 4.704 & 5.022 \\
\hline $\mathrm{Fe}(\mathrm{ii})$ & 0.013 & 0.016 & 0.007 & 0.014 \\
\hline $\mathrm{Ca}$ & 0.821 & 0.904 & 0.724 & 0.604 \\
\hline $\mathrm{Na}$ & 3.081 & 2.978 & 3.137 & 3.034 \\
\hline $\mathrm{K}$ & 0.047 & 0.044 & 0.072 & 0.043 \\
\hline $\mathrm{TOTAL}$ & 19.967 & 19.952 & 19.948 & 19.872 \\
\hline & & & & \\
\hline $\mathrm{An}$ & 20.79 & 23.02 & 18.42 & 16.40 \\
\hline $\mathrm{Ab}$ & 78.02 & 75.85 & 79.75 & 82.42 \\
\hline $\mathrm{Or}$ & 1.20 & 1.13 & 1.83 & 1.18 \\
\hline $\mathrm{X}$ Ab & 0.79 & 0.77 & 0.81 & 0.83 \\
\hline $\mathrm{X}$ An & 0.21 & 0.23 & 0.19 & 0.17 \\
\hline & & & & \\
\hline
\end{tabular}


Table-8: Geothermometry of Gray pegmatites.

\begin{tabular}{|c|c|c|c|c|c|c|c|}
\hline & 1 & 2 & 3 & 4 & 5 & 6 & \\
\hline \multicolumn{7}{|c|}{ Based on Hammarstorm and Zen $86\left(X_{A b}=0.79\right.$ and $\left.X_{A n}=0.21\right)$} & Average \\
\hline $\mathrm{P} \mathrm{kb}$ & 4.900 & 5.300 & 5.100 & 5.100 & 5.100 & 5.000 & 5.100 \\
\hline T (C) HB2 '94 & 776.1 & 768.5 & 760.8 & 754.9 & 746.5 & 742.0 & 758.1 \\
\hline $\mathrm{T}(\mathrm{C})$ & 760.8 & 759.2 & 754.3 & 749.8 & 745.1 & 748.1 & 752.9 \\
\hline \multicolumn{7}{|c|}{ Based on Hammarstorm and Zen $86\left(X_{A b}=0.77\right.$ and $\left.X_{A n}=0.23\right)$} & Average \\
\hline $\mathrm{P} \mathrm{kb}$ & 4.900 & 5.300 & 5.100 & 5.100 & 5.100 & 5.000 & 5.100 \\
\hline T (C) HB2 '94 & 787.1 & 779.5 & 771.8 & 765.8 & 757.4 & 752.7 & 769.1 \\
\hline $\mathrm{T}(\mathrm{C}) \mathrm{BH}$ '90 & 766.5 & 764.9 & 759.9 & 755.4 & 750.6 & 753.6 & 758.5 \\
\hline \multicolumn{7}{|c|}{ Based on Hollister et al. $87 \quad\left(\mathrm{X}_{\mathrm{Ab}}=0.79\right.$ and $\mathrm{X}_{\mathrm{An}=0.21)}$} & Aver \\
\hline $\mathrm{P} \mathrm{kb}$ & 5.100 & 5.600 & 5.400 & 5.400 & 5.300 & 5.200 & 5.300 \\
\hline T (C) HB2 '94 & 110.0 & 105.0 & 761.6 & 755.8 & 747.2 & 742.6 & 758.9 \\
\hline $\mathrm{T}(\mathrm{C}) \mathrm{BH}$ '90 & 757.8 & 754.5 & 749.7 & 745.3 & 742.1 & 745.0 & 749.1 \\
\hline \multicolumn{7}{|c|}{ Based on Hollister et al. $87\left(\mathrm{X}_{\mathrm{Ab}}=0.77\right.$ and $\mathrm{X}_{\mathrm{An}=0.23)}$} & Average \\
\hline $\mathrm{P} \mathrm{kb}$ & 5.100 & 5.600 & 5.400 & 5.400 & 5.300 & 5.200 & 5.300 \\
\hline T (C) HB2 '94 & 787.5 & 780.3 & 772.6 & 766.8 & 758.1 & 753.3 & 769.8 \\
\hline $\mathrm{T}\left(C_{1}\right.$ & 4 & 76 & 755.3 & 8 & 747.6 & 750 & 754.7 \\
\hline \multicolumn{7}{|c|}{ Based on Johnson and Rutherford $89\left(X_{A b}=0.79\right.$ and $\left.X_{A n}=0.21\right)$} & Average \\
\hline $\mathrm{P} \mathrm{kb}$ & 4.000 & 4.300 & 4.100 & 4.100 & 4.100 & 4.000 & 4.100 \\
\hline T (C) HB2 '94 & 774.3 & 765.8 & 757.9 & 751.8 & 743.1 & 739.0 & 755.3 \\
\hline $\mathrm{T}(\mathrm{C}) \mathrm{BH}$ '90 & 774.6 & 774.6 & 769.6 & 765.0 & 760.2 & 763.2 & 767.9 \\
\hline \multicolumn{7}{|c|}{ Based on Johnson and Rutherford $89\left(\mathrm{X}_{\mathrm{Ab}=0.77 \text { and }} \mathrm{X}_{\mathrm{An}=0.23)}\right.$} & Average \\
\hline r KD & 4.000 & 4.300 & 4.100 & 4.100 & 4.100 & 4.000 & 4.100 \\
\hline $\mathrm{T}(\mathrm{C}) \mathrm{HB} 2$ '94 & 785.3 & 776.7 & 768.8 & 762.7 & 753.9 & 7 & 766.2 \\
\hline $\mathrm{T}(\mathrm{C}) \mathrm{BH}$ '90 & 780.4 & 780.4 & 775.3 & 770.7 & 765.9 & 768.9 & 773.6 \\
\hline \multicolumn{7}{|c|}{ Based on Schmidt $92\left(X_{A b}=0.79\right.$ and $X_{A n=0.21)}$} & Average \\
\hline $\mathrm{P}(\mathrm{kb})$ & 5.30 & 5.70 & 5.50 & 5.50 & 5.50 & 5.40 & 5.50 \\
\hline T (C) HB2 '94 & 777.0 & 769.7 & 762.2 & 756.3 & 747.9 & 743.4 & 759.4 \\
\hline $\mathrm{T}(\mathrm{C}) \mathrm{BH}$ '90 & 753.7 & 752.7 & 747.0 & 742.9 & 738.6 & 741.2 & 746.0 \\
\hline \multicolumn{7}{|c|}{ Based on Schmidt $92\left(\mathrm{X}_{\mathrm{Ab}}=0.77\right.$ and $\left.\mathrm{X}_{\mathrm{An}=0.23}\right)$} & Average \\
\hline $\mathrm{P}(\mathrm{kb})$ & 5.30 & 5.70 & 5.50 & 5.50 & 5.50 & 5.40 & 5.50 \\
\hline T (C) HB2 '94 & 788.1 & 780.7 & 773.1 & 767.3 & 758.9 & 754.1 & 770.4 \\
\hline $\mathrm{T}(\mathrm{C}) \mathrm{BH}{ }^{\prime} 90$ & 759.3 & 758.3 & 752.6 & 748.5 & 744.1 & 746.7 & 751.6 \\
\hline
\end{tabular}


Table-9: Geothermometry of Pink Pegmatites.

\begin{tabular}{|c|c|c|c|c|c|c|c|}
\hline & 1 & 2 & 3 & 4 & 5 & 6 & \\
\hline \multicolumn{7}{|c|}{ Based on Hammarstorm and Zen $86\left(X_{A b}=0.81\right.$ and $\left.X_{A n}=0.18\right)$} & Average \\
\hline $\mathrm{P} \mathrm{kb}$ & 5.100 & 4.900 & 5.100 & 4.900 & 5.100 & 4.900 & 5.000 \\
\hline T (C) HB2 '94 & 743.3 & 775.1 & 738.6 & 751.7 & 743.4 & 751.9 & 750.6 \\
\hline $\mathrm{T}(\mathrm{C}) \mathrm{BH}$ '90 & 745.7 & 761.0 & 741.7 & 751.7 & 739.8 & 747.5 & 747.9 \\
\hline \multicolumn{7}{|c|}{ Based on Hammarstorm and Zen $86\left(\mathrm{X}_{\mathrm{Ab}}=0.83\right.$ and $\left.\mathrm{X}_{\mathrm{An}}=0.16\right)$} & Average \\
\hline $\mathrm{P} \mathrm{kb}$ & 5.100 & 4.900 & 5.100 & 4.900 & 5.100 & 4.900 & 5.000 \\
\hline T (C) HB2 '94 & 728.7 & 760.3 & 724.1 & 737.3 & 728.7 & 737.3 & 736.0 \\
\hline $\mathrm{T}(\mathrm{C}) \mathrm{BH}$ '90 & 741.5 & 756.8 & 737.6 & 747.5 & 735.7 & 743.3 & 743.7 \\
\hline \multicolumn{7}{|c|}{ Based on Hollister et al. $87\left(\mathrm{X}_{\mathrm{Ab}=0.81 \text { and }} \mathrm{X}_{\mathrm{An}}=0.18\right)$} & AVEI \\
\hline $\mathrm{P} \mathrm{kb}$ & 5.400 & 5.200 & 5.300 & 5.200 & 5.300 & 5.100 & 5.200 \\
\hline T (C) HB2 '94 & 744.2 & 775.6 & 739.2 & 752.4 & 744.0 & 752.4 & 751.3 \\
\hline $\mathrm{T}(\mathrm{C}) \mathrm{BH}$ '90 & 741.1 & 756.4 & 738.7 & 747.2 & 736.7 & 744.4 & 744.1 \\
\hline \multicolumn{7}{|c|}{ Based on Hollister et al. $87\left(\mathrm{X}_{\mathrm{Ab}=0.83}\right.$ and $\left.\mathrm{X}_{\mathrm{An}}=0.16\right)$} & Average \\
\hline $\mathrm{P} \mathrm{kb}$ & 5.400 & 5.200 & 5.300 & 5.200 & 5.300 & 5.100 & 5.200 \\
\hline T (C) HB2 '94 & 729.6 & 760.8 & 724.7 & 738.0 & 729.3 & 737.7 & 736.7 \\
\hline $\mathrm{T}(\mathrm{C}) \mathrm{BH}$ '90 & 737.0 & 752.2 & 734.6 & 743.0 & 732.7 & 740.3 & 740.0 \\
\hline \multicolumn{7}{|c|}{ Based on Johnson and Rutherford $89\left(\mathrm{X}_{\mathrm{Ab}}=0.81\right.$ and $\left.\mathrm{X}_{\mathrm{An}}=0.18\right)$} & Average \\
\hline $\mathrm{P} \mathrm{kb}$ & 4.200 & 4.000 & 4.100 & 4.000 & 4.100 & 3.900 & 4.000 \\
\hline $\mathrm{T}(\mathrm{C}) \mathrm{HB} 2$ '94 & 740.4 & 773.5 & 735.4 & 749.6 & 740.1 & 749.4 & 748.1 \\
\hline $\mathrm{T}(\mathrm{C}) \mathrm{BH}$ '90 & 759.3 & 774.8 & 756.8 & 765.4 & 754.8 & 762.6 & 762.3 \\
\hline \multicolumn{7}{|c|}{ Based onJohnson and Rutherford $89\left(\mathrm{X}_{\mathrm{Ab}}=0.83\right.$ and $\left.\mathrm{X}_{\mathrm{An}}=0.16\right)$} & Average \\
\hline P kb & 4.200 & 4.000 & 4.100 & 4.000 & 4.100 & 3.900 & 4.000 \\
\hline T (C) HB2 '94 & 725.9 & 758.8 & 720.9 & 735.2 & 725.5 & 734.8 & 733.5 \\
\hline $\mathrm{T}(\mathrm{C}) \mathrm{BH} ' 90$ & 755.1 & 770.5 & 752.6 & 761.2 & 750.7 & 758.4 & 758.1 \\
\hline \multicolumn{7}{|c|}{ Based on Schmidt, $92\left(\mathrm{X}_{\mathrm{Ab}}=0.81\right.$ and $\mathrm{X}_{\mathrm{An}=0.18)}$} & Average \\
\hline $\mathrm{P}(\mathrm{kb})$ & 5.60 & 5.40 & 5.50 & 5.40 & 5.50 & 5.30 & 5.40 \\
\hline $\mathrm{T}(\mathrm{C}) \mathrm{HB} 2$ '94 & 744.9 & 775.9 & 739.9 & 752.8 & 744.7 & 753.0 & 751.9 \\
\hline $\mathrm{T}(\mathrm{C}) \mathrm{BH}{ }^{\prime} 90$ & 738.1 & 753.3 & 735.5 & 744.0 & 733.7 & 740.7 & 740.9 \\
\hline \multicolumn{7}{|c|}{ Based on Schmidt, $92\left(X_{A b}=0.83\right.$ and $\left.X_{A n=0.16}\right)$} & Average \\
\hline $\mathrm{P}(\mathrm{kb})$ & 5.60 & 5.40 & 5.51 & 5.41 & 5.50 & 5.35 & 5.40 \\
\hline $\mathrm{T}(\mathrm{C}) \mathrm{HB} 2$ '94 & 730.3 & 761.1 & 725.3 & 738.4 & 730.0 & 738.4 & 737.3 \\
\hline $\mathrm{T}(\mathrm{C}) \mathrm{BH}$ '90 & 734.0 & 749.0 & 731.4 & 739.9 & 729.7 & 736.5 & 736.8 \\
\hline
\end{tabular}

